Federal Reserve Bank of Dallas

Globalization and Monetary Policy Institute

Working Paper No. 288

http://www.dallasfed.org/assets/documents/institute/wpapers/2016/0288.pdf

\title{
Financial Performance and Macroeconomic Fundamentals in Emerging Market Economies over the Global Financial Cycle*
}

\author{
Scott Davis \\ Federal Reserve Bank of Dallas \\ Andrei Zlate \\ Federal Reserve Bank of Boston
}

September 2016

\begin{abstract}
This paper explores the relationship between financial performance and macroeconomic fundamentals in emerging market economies not only in times of crises, but in general during crisis and non-crisis years over the global financial cycle. Using a panel framework with data for 119 emerging market economies at an annual frequency, we examine whether the relationship between performance and fundamentals varies in magnitude and/or switches sign between crisis and non-crisis years. We find that better macroeconomic fundamentals (such as a stronger net foreign asset positions and higher stocks of foreign exchange reserves) are associated with better financial performance not just during crisis episodes, but also during normal times. Quantitatively, the impact of fundamentals on performance is smaller during normal times than during crisis years, but works in the same direction and is statistically significant. The results are consistent with those of recent empirical studies on the link between financial performance and fundamentals during episodes of global financial stress, but generalizes the results to the global financial cycle.
\end{abstract}

JEL codes: F3, E5

\footnotetext{
* Scott Davis, Federal Reserve Bank of Dallas, Research Department, 2200 N. Pearl Street, Dallas, TX 75201. 214-922-5124. scott.davis@dal.frb.org. Andrei Zlate, Federal Reserve Bank of Boston, 600 Atlantic Avenue, Boston, MA 02210.617-973-6383. andrei.zlate@bos.frb.org. We would like to thank Ji Zhang and participants at the 2016 Econometric Society North American Summer Meetings in Philadelphia for very helpful suggestions, as well as Eric Haavind-Berman for excellent research assistance. The views in this paper are those of the authors and do not necessarily reflect the views of the Federal Reserve Bank of Boston, the Federal Reserve Bank of Dallas or the Federal Reserve System.
} 


\section{Introduction}

In May 2013, then Fed chairman Ben Bernanke mentioned in congressional testimony that the Fed would begin to curtail, or "taper", the asset purchase program commonly known as QE3. In subsequent post-meeting statements, the Fed reaffirmed their commitment to tapering the asset purchase program.

Many had concluded that asset purchase programs like QE3 led to extraordinary capital inflows into many emerging market and developing countries, placing upward pressure on their exchange rates. In turn, this upward pressure was manifested in either exchange rate appreciation or expanding central bank reserves. Later on, the thought of a curtailment in programs like QE3 led to the expectation of a reversal in capital flows into these countries. Expecting currency depreciation and falling asset prices, private capital began to flee many emerging markets at the mere suggestion of tapering, and many emerging markets experienced a near-crisis episode, dubbed the "taper tantrum", in the summer of 2013.

During the taper tantrum episode in 2013, certain countries were deemed by the market to be particularly vulnerable to a reversal in capital flows, and thus suffered larger declines in currency and asset values. In particular, the "fragile five" were the group of 5 large emerging market countries with relatively weak macroeconomic fundamentals (Brazil, India, Indonesia, Turkey, and South Africa). The thought was that these countries depended on positive net capital inflows to finance their current account deficits, so the possible reversal in capital flows may hit them particularly hard (see e.g. Ahmed, Coulibaly, and Zlate (2015); Aizenman, Binici, and Hutchison (2014); Mishra, Moriyama, and N'Diaye (2014)).

While the effect of macroeconomic fundamentals (such as the current account balance) on exchange rate performance during crisis episodes has been relatively well-studied, less is known about how fundamentals affect exchange rate performance and exchange rate pressure during normal, non-crisis times. If countries with weaker fundamentals underperform their piers with stronger fundamentals during a crisis, do they also underperform during normal times? Or, on the contrary, are weaker fundamentals only seen as leading to vulnerability 
during a crisis, but are ignored by the market and private capital flows during non-crisis times? This paper examines the relationship between financial performance and macroeconomic fundamentals in emerging market economies that is observed not only in times of crises, but in general during crisis and non-crisis years over the global financial cycle. ${ }^{1}$

Our paper attempts to answer these questions by exploring the relationship between financial performance and macroeconomic fundamentals over the cycle, rather than just during specific crisis episodes. Using a panel econometric specification with annual data, we examine the link between financial performance (i.e., currency appreciation and appreciation pressure) and macroeconomic fundamentals (i.e., the current account balance, the net foreign asset positions, the stock of foreign exchange reserves, GDP growth, and inflation). In addition, we use interacted terms between macroeconomic fundamentals and a "crisis year" dummy variable to determine whether the relationship between macroeconomic fundamentals and financial performance is robust, varies in magnitude, or switches signs between crisis and non-crisis years.

We find that better macroeconomic fundamentals, such as a stronger net foreign asset position and a higher stock of foreign exchange reserves, are associated with better financial performance not just during crisis episodes, but also during normal times. Quantitatively, the impact of fundamentals on financial performance is larger during the crisis years themselves than outside of crisis years, but the coefficient is still positive and statistically significant during normal times. Thus, countries with relatively stronger fundamentals suffered less currency depreciation and depreciation pressure during an episode like the global financial crisis in the fall and winter of 2008-09, a finding which is consistent with Ferretti and Razin (2000), Rose and Spiegel (2011), Frankel and Saravelos (2012), and Lane and Milesi-Ferretti (2011, 2012). However, we find that countries with stronger fundamentals also experienced more currency appreciation and appreciation pressure during normal times, such as during

\footnotetext{
${ }^{1}$ Since exchange rate pressure and capital flows are intimately related, this analysis adds to the empirical literature that explores the determinants of capital flows to emerging market economies ((Ahmed and Zlate 2014); (Forbes and Warnock 2012); (Ghosh, Qureshi, Kima, and Zalduendo 2014)).
} 
the 2009 recovery.

Our approach has a number of advantages over those used in the afore-mentioned studies. First, we do not restrict our analysis to specific crisis episodes, but explore the robustness of the link between macroeconomic fundamentals and relative exchange rate performance over the cycle, during both booms and busts. A time fixed effect in the panel data regression controls for global factors, allowing us to examine the role of country-specific factors in determining the relative performance across emerging markets. Second, instead of limiting our analysis to the behavior of capital flows, we examine the performance of the financial markets affected by these capital flows (such as foreign exchange markets). Using financial variables as dependent variables allows much wider cross-sectional and cross-time coverage than it would be possible with other indicators like capital flows. Third, we do not just consider the role of current account positions, as in most discussions of the financial performance in the "fragile five", but expand the analysis to consider the impact of other country-specific fundamentals, like the stock of external debt or foreign exchange reserves, on financial performance. ${ }^{2}$ Interestingly, we find that while the stocks of certain type of assets, like external debt or central bank reserves, are important determinates of financial performance, other external assets, like portfolio equity or FDI, have less important roles.

Measuring financial performance at the annual frequency is the outcome of a trade-off between precision in measuring financial performance and feasibility in constructing the panel dataset. On one hand, while good times are prolonged and smooth, crises are sort and with bounce-backs, so the annual data may not capture the full collapse of financial markets when some partial recovery happens within the same year. However, the finding of stronger effects of fundamentals during crises than non-crisis years, as discussed above, alleviates this concern. On the other hand, the use of annual performance allows for the construction of a panel dataset without arbitrarily choosing start and end dates for the boom and crisis episodes, which are not necessarily aligned across emerging market economies. The use

\footnotetext{
${ }^{2}$ Obstfeld (2012) argues that current account deficits don't matter as much as imbalances in stock of external assets and liabilities.
} 
of annual data also expands the sample coverage to 119 emerging market and developing economies.

Our paper may also shed some light on an apparent puzzle that prevails in the empirical literature on the link between fundamentals and financial performance during episodes of global financial stress. Namely, how does one reconcile that: (1) countries with worse fundamentals fare worse during stress episodes (see e.g. Ahmed, Coulibaly, and Zlate (2015); Mishra, Moriyama, and N'Diaye (2014)); and (2) countries that receive more capital inflows ex-ante also fare worse during such episodes (see e.g. Lane and Milesi-Ferretti (2011, 2012); Eichengreen and Gupta (2014))? One possible explanation would have been that countries with worse fundamentals receive more capital inflows during booms (and hence experience more appreciation) and suffer more outflows during crises (and hence experience more depreciation), which would have made (1) and (2) consistent with one another. However, this first explanation is not supported by our results, which suggest that countries with worse fundamentals not only suffer greater net capital outflows and underperform during crises, but also receive less net capital inflows and underperform during booms. Another possible explanation would be that countries that initially have better fundamentals receive more inflows during booms (and hence experience more appreciation), which erodes the strength of their fundamentals (e.g., their next foreign assets position deteriorates as they become more indebted); in turn, these countries experience larger outflows during crisis (and hence suffer more depreciation). In this version of events, relatively stronger fundamentals invite capital inflows during good times, which then erode fundamentals and sow the seeds of destruction during crisis times. While our results are consistent with the second explanation, more research is needed to examine this topic. ${ }^{3}$

The rest of this paper is organized as follows. A simple example of the importance of economic fundamentals like the current account and stock of net external assets in driving

\footnotetext{
${ }^{3}$ See e.g. the discussion of capital flow bonanzas in McKinnon and Pill (1996), Magud, Reinhart, and Vesperoni (2011), Kaminsky and Reinhart (1999), Barrell, Davis, Karim, and Liadze (2010), Reinhart and Reinhart (2009), Reinhart and Rogoff (2011).
} 
relative exchange rate performance during the global financial crisis in 2008-09 is presented in section 2. The example considers exchange rate performance in emerging markets both during the downturn (from the collapse of Lehman Brothers in September 2008 through the trough in March 2009), when currencies depreciated sharply, and during the subsequent recovery (from March through the end of 2009), when currencies rallied and appreciated against the dollar. The econometric specification and data used in our panel estimation are presented in section 3. The results from this panel data study are presented in section 4 . Finally section 5 concludes with a discussion of directions for further research.

\section{Exchange rates and fundamentals in 2008-09}

In this paper, we consider exchange rate fluctuations and exchange rate pressure for the sample of 119 emerging market and developing countries listed in Table 1. As one interesting case for this sample of countries, Figure 1 shows simple averages of nominal exchange rates over the period from September 2008 to December 2009, with the sample divided into groups by the strength of their fundamentals (and the rates indexed to 1 on September 1, 2008).

The simple average across all countries is shown by the green line in the top left-hand panel. It shows that between September 2008 and early March 2009, the sample currencies depreciated on average by $14 \%$ against the U.S. dollar. Conversely, during the recovery from March 2009 through the end of 2009, these currencies appreciated by about $10 \%$ against the dollar. In the same top left-hand panel, the red and blue lines represent average exchange rates where for two country groups defined according to the relative strength of their fundamentals as of 2007, namely countries with above-median current account to GDP ratios (blue line) and those with below-median current account to GDP ratios (red line). The figure shows that although both groups of currencies tended to depreciate against the dollar during the crisis, the currencies of countries with below-median current account to GDP ratios tended to depreciate by more, underperforming those with above-median current accounts by 
around 2 percentage points at the height of the crisis. Also, by December 2009, currencies in countries with above-median current account ratios recovered relatively by more: they were about $3 \%$ lower than the pre-crisis peak, whereas those in countries with below-median current account ratios were still below the peak by as much as $7 \%$.

Average exchange rates for the same sample are plotted in the top right-hand panel, but here the countries are divided into two groups based on those with above and below median levels of central bank foreign exchange reserves to GDP. The figure shows the same pattern as in the previous one, i.e., during the crisis, a gap opened between the two groups, and this gap expanded during the subsequent recovery. Thus, countries with better fundamentals, i.e., a high stock of central bank foreign exchange reserves, outperformed those with worse fundamentals during both the crisis and the recovery periods.

Average exchange rates are also plotted in the lower left-hand panel, where countries are split into those with above and below the median net external debt assets to GDP. A gap between the two lines emerged during the crisis, as the currencies of countries with high amounts of external debt on average underperformed those of countries with less external debt during the crisis. However, this gap does not appear to widen during the recovery, suggesting that, unlike the current account or foreign exchange reserves, net external debt was not a major driver of relative exchange rate performance during the recovery.

Finally, the last chart in the figure splits the sample of countries into those with above and below the median net external FDI assets to GDP ratio. Here, no gap emerges between the two lines during either the crisis or the recovery, suggesting that the net external FDI position was not a driver of relative exchange rate performance during either the crisis or the recovery period. 


\section{Econometric methodology and data}

Our econometric specification consists of simple regressions in a panel framework with annual data, in which the dependent variable measures financial performance and the explanatory variables reflect the relative strength of macroeconomic fundamentals:

$$
F_{i t}=\alpha_{i}+\alpha_{t}+\boldsymbol{\beta}^{\prime} \boldsymbol{\theta}_{i t-1}+X_{t} \gamma^{\prime} \boldsymbol{\theta}_{i t-1}+\varepsilon_{i t}
$$

where $F_{i t}$ is a measure of financial performance during year $t$, reflecting either the change in the nominal exchange rate or an exchange rate pressure index, $\boldsymbol{\theta}_{i t-1}$ is a vector of lagged economic fundamentals, including the current account to GDP ratio, the net foreign asset position, GDP growth, and inflation, and $X_{t}$ is an indicator variable that takes the value of 1 if year $t$ is deemed to be an "emerging market currency crisis year". The panel data specification also includes country fixed effects to control for unobserved country characteristics and time fixed effects to control for time-variant global factors.

The net external assets to GDP ratio can be decomposed into central bank reserves, net external debt, and net external equity (both portfolio equity and FDI). ${ }^{4}$ Thus, in an alternative specification, we can treat each type of net external assets as a separate variable in $\boldsymbol{\theta}_{i t-1}$.

The time fixed effects control for time-variant global factors, which may determine for instance whether emerging market currencies on average appreciate or depreciate relative to the dollar in a given year. Thus, in this specification, the components of $\boldsymbol{\beta}$ and $\boldsymbol{\gamma}$ measure to what extent economic fundaments like the current account or the net foreign asset position affect the relative financial performance across emerging markets. In addition, the interactions between each of these fundamentals and the crisis year dummy $X_{t}$ allow to distinguish between the effect of fundamentals on the relative financial performance during normal,

\footnotetext{
${ }^{4}$ According to the IMF's Balance of Payments manual, a purchase of the ownership stake in a foreign company or project is an equity based capital flow. The IMF BOP definitions use the $10 \%$ rule. If the purchase is more than $10 \%$ of the total market value, it is defined as an FDI flow. If less than 10\%, it is defined as a portfolio equity flow (see (International Monetary Fund 2009)).
} 
non-crisis times from the effect during crisis times. Importantly, the components of $\boldsymbol{\beta}$ tell us whether in normal times countries with better fundamentals experience more (or less) currency appreciation than countries with weaker fundamentals. Also, the components of $\gamma$ show how the effect of fundamentals on relative performance changes during crisis years, i.e., whether countries with better fundamentals fare even better during crisis years than those with weaker fundamentals.

\subsection{Data}

The panel dataset contains 119 developing and emerging market countries. The unbalanced panel consists of annual data, potentially from 1972 to 2011. The data on exchange rates, foreign exchange reserves, the current account, and the net foreign asset positions are from Lane and Milesi-Ferretti (2007).

As dependent variables, in alternative specifications, we use either the change in the nominal exchange rate during the course of the year or the exchange rate pressure index. The exchange rate pressure index is measured as the percent change in the nominal exchange rate minus the change in reserves. Thus, a downward movement in either the exchange rate or the pressure index indicates appreciation.

As explanatory variables, we use macroeconomic fundamentals such as the current account balance and the net external assets position (all normalized by GDP). We decompose net external assets into four components, i.e., net external debt, net external portfolio equity, net external FDI, and the stock of foreign exchange reserves. We also consider the roles of gross government debt, GDP growth, and inflation as a potential fundamental variables driving exchange rate movements.

Descriptive statistics for each of the variables in the model are presented in Table 2. The crisis indicator variable $X_{t}$ takes a value of 1 if the year is an "emerging market currency crisis" year and 0 otherwise. The crisis year is defined as a year of widespread emerging market currency crisis, rather than being country specific. As such, $X_{t}=1$ denotes a year 
when more than 5 percent of the countries in the sample suffered a currency crisis according to the Laeven and Valencia (2013) currency crisis index. Using this 5 percent cutoff, the crisis years are 1981, 1983, 1984, 1985, 1989, 1990, 1992, 1994, 1998, and 1999. The results are robust to cutoffs between 3-to-7 percent. Above 7 percent, there are nearly no crisis years (1994 is the only crisis year when the cutoff is above 8 percent), whereas below 3 percent nearly every year is a crisis year.

\section{Results}

Before presenting the results from the multivariate regression, it is helpful to first visually examine the relation between the changes in exchange rates over a given year against economic fundamentals measures as of the beginning of that year. The corresponding scatter plots are presented in Figure 2. Each scatter plot shows the country-year observations for the full sample; the blue solid line is the least-squares fit through the country-year observations for emerging market crisis years; the red dotted line is the least-squares projection through the country-year observations for years that were not emerging market crisis years.

Each of the four scatter plots shows a relationship between lagged fundaments and exchange rate performance in both crisis and non-crisis years. For the current account/GDP ratio, net external assets/GDP ratio, and central bank reserves/GDP ratio, the slope of the least squares fit is negative, indicating that a stronger current account or external assets position is associated with exchange rate appreciation. On the contrary, the slope of the fit line in the figure with gross government debt/GDP is positive, indicating that higher amounts of government debt are associated with exchange rate depreciation.

The estimated slope coefficients in these univariate regressions are presented in Table 3. In nearly every case, the estimated slope is significant and has the appropriate sign during both crisis years and non-crisis years. The one exception is the univariate regression involving the current account in crisis years, where the point estimate is large and has the 
expected sign, but the standard error is also large. In most cases, the absolute value of the slope during crisis years is larger than the absolute value of the slope during non-crisis years. The result suggests that the relation between lagged fundamentals and exchange rate performance from non-crisis years is preserved and actually amplified during crisis years.

\subsection{Results from the multivariate panel data regression}

We present panel data results from the regression of financial performance in a given year on a set of macroeconomic fundamentals from the previous year. In alternative specifications, the dependent variables include either the change in exchange rates (Table 4) or the exchange rate pressure index (Table 5), with a downward movement denoting appreciation or appreciation pressure. Among the explanatory variables, each table includes macroeconomic fundamentals such as the current account balance and the net external assets position, controls for GDP growth and inflation, as well as time and country fixed effects. The net external assets enter either in the aggregate (columns 2 and 3), split between foreign exchange reserves and nonreserve assets (columns 4 and 5), or split into net external debt assets, net external portfolio equity assets, net external FDI assets, and net foreign exchange reserves (columns 6 and 7). For each set of controls in columns 2-7, the table shows results from regressions with the fundamentals included alone or interacted with the crisis dummy $X_{t}$.

The results suggest that, without distinguishing between crisis and non-crisis years, better macroeconomic fundamentals are associated with better financial performance, with the latter defined as more currency appreciation (Table 4) and stronger upward pressure on exchange rates (Table 5). In all specifications, faster lagged GDP growth and lower lagged inflation are associated with more appreciation pressure.

When included as the only fundamental variable other than GDP growth and inflation, the current account balance has a negative and statistically significant effect on relative performance, with a higher current account balance coinciding with greater exchange rate appreciation. This result also holds when net external assets (including reserves) are included 
in the regression. But when central bank reserves are included as a separate variable in the regression (columns 4-7 in Tables 4 and 5), the current account no longer has a statistically significant effect on relative performance. The current account is statistically significant in the first three columns, i.e., when net external assets are either excluded from the specification or they are included but as one term without separating out reserves. Once reserves enter as a separate variable, the current account loses significance.

Furthermore, the results in columns 4 and 5 show that net external assets (excluding foreign exchange reserves) have a positive and significant effect on relative exchange rate performance. However, in columns 6 and 7, external assets are further decomposed into portfolio equity, FDI, and debt. In these specifications, debt is the only variable that has an effect on relative exchange rate performance. The net external FDI or portfolio equity positions have no effect on relative financial performance. This finding echoes that in McKinnon and Schnabl (2004a, 2004b), who argue that the stock of foreign currency-denominated assets is an important factor for exchange rate stabilization. Both FDI and portfolio equity tend to be denominated in the home currency, whereas in most emerging market countries, the stocks of external debt and central bank reserves are denominated in foreign currencies.

Distinguishing between crisis and non-crisis years, we find that macroeconomic fundamentals still affect exchange rates in non-crisis years. Earlier we asked the crucial question of whether in normal, non-crisis times, do countries with stronger fundamentals experience more currency appreciation than countries with weaker fundamentals? We provide an answer to this question by including interactions between lagged fundamentals and $X_{t}$, the emerging market crisis dummy, into the regression. In these specifications, the lagged fundamentals by themselves still have a statistically significant effect, suggesting that fundamentals affect relative performance not only in a crisis year but in normal times as well.

Furthermore, the results show that during years characterized as "emerging market currency crisis" years, the effect of economic fundamentals on relative performance across emerging market and developing countries is even larger than in normal years. For instance, in 
column 5 of Table 4, a 1 percentage point increase in the stock of central bank reserves leads to a $0.158 \%$ relative appreciation in the exchange rate in a normal year, but a $0.392 \%$ (i.e., $0.158 \%+0.234 \%$ ) relative appreciation during a crisis year. Thus, macroeconomic fundamentals explain some of the cross-country differences in relative exchange rate performance during normal years, but their effect is magnified during emerging market crisis years.

In Table 6, we include the lagged gross government debt measured relative to GDP among the fundamentals, while using the specification with foreign exchange reserves separated from next external assets. In the full sample of 119 emerging market economies, less government debt is associated with more exchange rate appreciation (columns 1-2) and more appreciation pressure (columns 3-4). However, the coefficient on the interacted term between government debt and the crisis indicator is not statistically significant, suggesting that the effect is not distinguishable between crisis and non-crisis years.

\section{Conclusion}

The repeated experience of financial crises in emerging market economies shows that, during crisis episodes, certain macroeconomic fundamentals like the current account balance, the stock of external assets, or the stock of reserves are important determinants of the relative financial performance across countries. For example, during the recent taper tantrum episode in 2013, the emerging market economies with large current account deficits (e.g., Brazil, India, Indonesia, South Africa, and Turkey, deemed the "fragile five") experienced significant exchange rate depreciation relative to those emerging markets with current account surpluses.

Given the importance of fundamentals during crisis times, it is natural to ask whether these same fundamentals have an effect on relative performance during normal times as well. We find that the answer is yes, they do. Thus, the stock of net external debt and the stock of central bank reserves seem to have robust and statistically significant effects on financial performance; in contrast, the stock of net external equity assets (either portfolio 
equity or FDI) do not seem to affect relative performance. Also, while these fundamentals have qualitatively similar effects on relative performance during normal times as during crisis times, we find that their effect is quantitatively larger during crisis times.

As mentioned in the introduction, the joint finding in the literature that (1) countries with worse fundamentals fare worse during stress episodes, and (2) countries that receive more capital inflows ex-ante also fare worse during such episodes raises a potential puzzle. The puzzle could have been explained if the same countries with worse fundamentals received more capital inflows during booms (and hence experience more appreciation) and suffered more outflows during crisis (and hence suffer more depreciation). However, this scenario is not supported by our results, which suggest that fundamentals push relative exchange rate performance in the same direction during crisis years as during normal, non-crisis times.

Another possible explanation would be that countries that initially have better fundamentals receive more inflows during booms (and hence experience more appreciation), which erodes the strength of their fundamentals (e.g., their net foreign assets position deteriorates as they become more indebted); in turn, these countries experience larger outflows during crisis (and hence suffer more depreciation). In this version of events, strong fundamentals invite capital flows during good times, which then erode fundamentals and leave emerging markets vulnerable during crisis times. Consistent with the findings of this paper, the way that strong economic fundamentals may encourage harmful "capital flow bonanzas" is an important direction for further research. 


\section{References}

Ahmed, S., B. Coulibaly, and A. Zlate (2015): "International Financial Spillovers to Emerging Market Economies: How Important Are Economic Fundamentals?," International Finance Discussion Papers 1135.

Ahmed, S., And A. Zlate (2014): "Capital flows to emerging market economies: a brave new world?," Journal of International Money and Finance, 48, 221-248.

Aizenman, J., M. Binici, and M. M. Hutchison (2014): "The transmission of Federal Reserve tapering news to emerging financial markets," NBER Working Paper No. 19980.

Barrell, R., E. Davis, D. Karim, and I. Liadze (2010): "Does the Current Account Balance help to Predict Banking Crises in OECD Countries?," mimeo.

Eichengreen, B., And P. Gupta (2014): "Tapering talk: the impact of expectations of reduced federal reserve security purchases on emerging markets," World Bank Policy Research Working Paper, (6754).

Ferretti, G. M. M., And A. Razin (2000): "Current account reversals and currency crises: empirical regularities," in Currency crises, ed. by P. Krugman, pp. 285-323. University of Chicago Press.

Forbes, K., and F. E. Warnock (2012): "Capital flow waves: Surges, stops, flight, and retrenchment," Journal of International Economics, 88, 235-251.

Frankel, J. A., and G. Saravelos (2012): "Can leading indicators assess country vulnerability? Evidence from the 2008 Ü09 global financial crisis," Journal of International Economics, 87(2), 216-231.

Ghosh, A. R., M. S. Qureshi, J. I. Kima, And J. Zalduendo (2014): "Surges," Journal of International Economics, 92, 266-285.

International Monetary Fund (2009): Balance of Payments and International Investment Position Manual. International Monetary Fund, Washington D.C.

Kaminsky, G. L., and C. M. Reinhart (1999): "The Twin Crises: The Causes of Banking and Balance-of-Payments Problems," American Economic Review, 89(3), 473-500.

Laeven, L., and F. Valencia (2013): "Systematic Banking Crises Database," IMF Economic Review, 61, 225-270.

Lane, P. R., And G. M. Milesi-Ferretti (2007): "The external wealth of nations mark II: Revised and extended estimates of foreign assets and liabilities, 1970-2004," Journal of International Economics, 73, 223-250.

(2011): "The Cross-Country Incidence of the Global Crisis," IMF Economic Review, $59,77-110$. 
- (2012): "External Adjustment and the Global Crisis," Journal of International Economics, 88(2), 252-265.

Magud, N. E., C. M. Reinhart, and E. R. Vesperoni (2011): "Capital Inflows, Exchange Rate Flexibility, and Credit Booms," NBER Working Paper No. 17670.

McKinnon, R., and G. Schnabl (2004a): "The East Asian dollar standard, fear of floating, and original sin," Review of Development Economics, 8(3), 331-360.

(2004b): "The return to soft dollar pegging in East Asia: mitigating conflicted virtue," International finance, 7(2), 169-201.

McKinnon, R. I., And H. Pill (1996): "Credible Liberalizations and International Capital Flows: The Overborrowing Syndrome," in Financial Deregulation and Integration in East Asia, NBER-EASE Volume 5, ed. by T. Ito, and A. O. Krueger, pp. 7-50. University of Chicago Press.

Mishra, P., K. Moriyama, and P. N'Diaye (2014): "Impact of Fed Tapering Announcements on Emerging Markets," .

Obstfeld, M. (2012): "Financial flows, financial crises, and global imbalances," Journal of International Money and Finance, 31(3), 469-480.

Reinhart, C., and V. Reinhart (2009): "Capital Flow Bonanzas: An Encompassing View of the Past and Present," NBER International Seminar on Macroeconomics 2008, pp. 9-62.

Reinhart, C. M., and K. S. Rogoff (2011): "From Financial Crash to Debt Crisis," American Economic Review, 101, 1676-1706.

Rose, A. K., and M. M. Spiegel (2011): "Cross-country causes and consequences of the crisis: An update," European Economic Review, 55(3), 309-324. 
Table 1: Countries in the charts and panel data regressions.

\begin{tabular}{cccc}
\hline \hline Angola & Dominican Republic & Sri Lanka & Russian Federation \\
Albania & Algeria & Lesotho & Rwanda \\
Armenia & Ecuador & Lithuania & Sudan \\
Azerbaijan & Egypt & Latvia & Senegal \\
Burundi & Estonia & Morocco & Sierra Leone \\
Benin & Ethiopia & Moldova & El Salvador \\
Burkina Faso & Fiji & Madagascar & Serbia \\
Bangladesh & Gabon & Maldives & Sao Tome and Principe \\
Bulgaria & Georgia & Mexico & Suriname \\
Bosnia and Herzegovina & Ghana & Macedonia, FYR & Slovak Republic \\
Belarus & Guinea & Mali & Slovenia \\
Belize & Equatorial Guinea & Mongolia & Swaziland \\
Bolivia & Grenada & Mozambique & Seychelles \\
Brazil & Guatemala & Mauritania & Syrian Arab Republic \\
Bhutan & Guyana & Mauritius & Chad \\
Botswana & Honduras & Malawi & Togo \\
Central African Republic & Croatia & Malaysia & Thailand \\
Chile & Haiti & Namibia & Trinidad and Tobago \\
China & Hungary & Niger & Tunisia \\
Cote d'Ivoire & Indonesia & Nigeria & Turkey \\
Cameroon & India & Nicaragua & Tanzania \\
Congo & Israel & Nepal & Uganda \\
Colombia & Jordan & Pakistan & Ukraine \\
Comoros & Kazakhstan & Panama & Uruguay \\
Cape Verde & Kenya & Peru & Venezuela \\
Costa Rica & Kyrgyz Republic & Philippines & Viet Nam \\
Czech Republic & Cambodia & Papua New Guinea & Yemen \\
Djibouti & Kuwait & Poland & South Africa \\
Dominica & Laos & Paraguay & Zambia \\
Democratic Republic of the Congo & Lebanon & Romania & \\
& & &
\end{tabular}



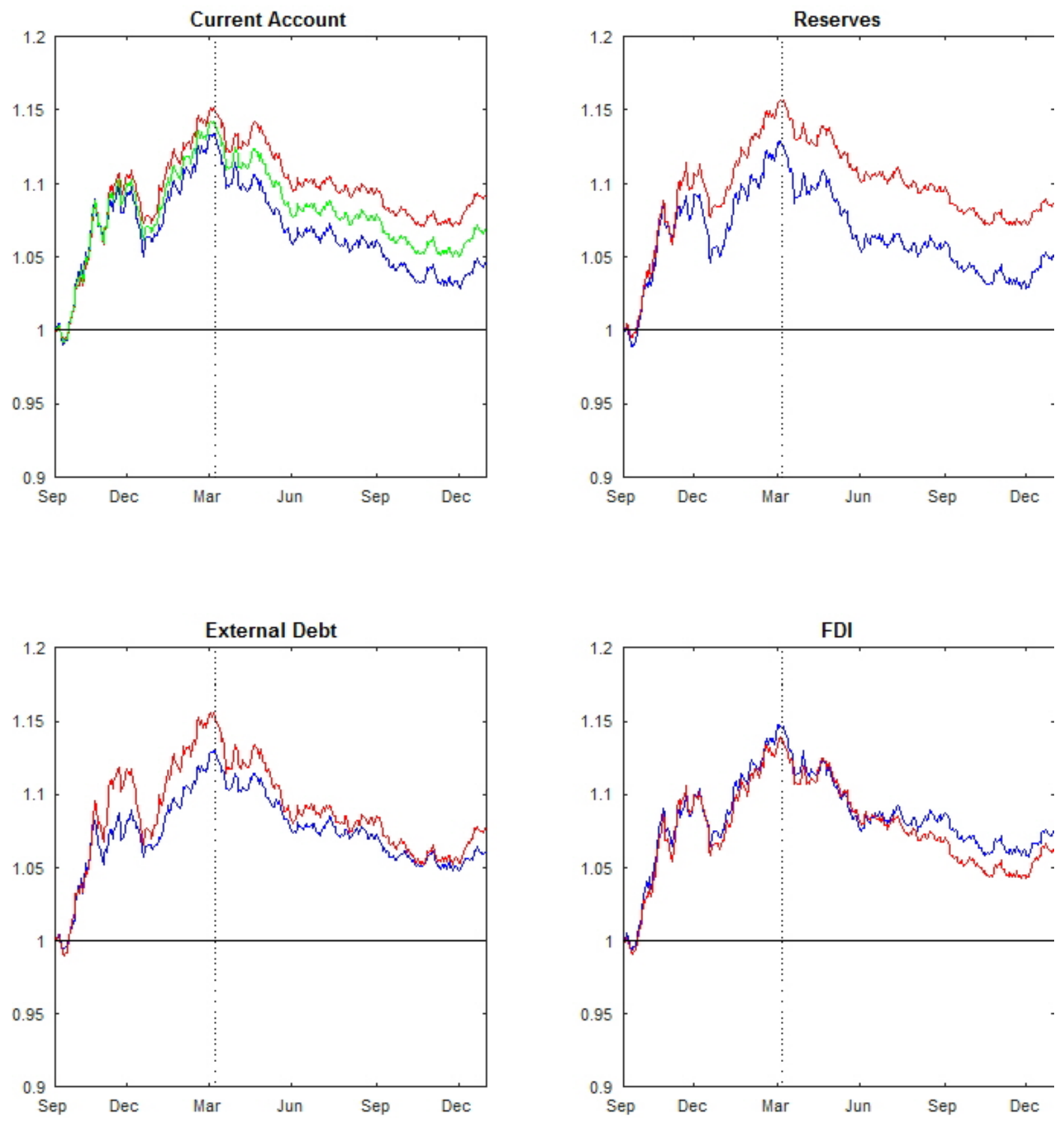

Figure 1: Simple average of the path of the nominal exchange rate vs. the U.S. dollar in emerging market and developing countries over the September 2008 to December 2009 period. The blue line is the simple average over those with above median current account or net external asset to GDP ratios and the red line is the simple average of those below the median. 

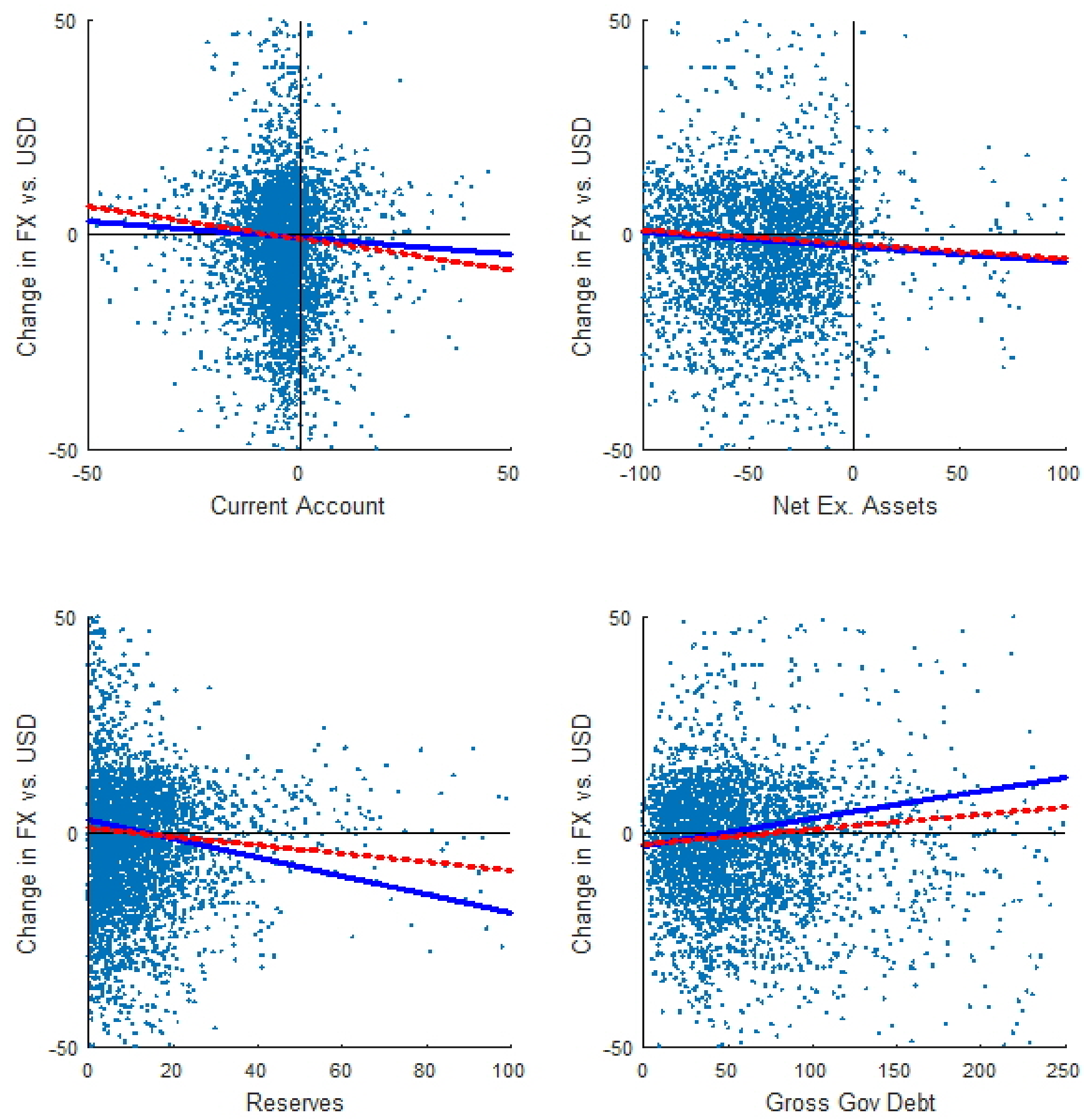

Figure 2: Scatter plots of the change in the nominal exchange rate in a given country over a given year against economic fundamentals at the beginning of that year. 
Table 2: Summary statistics with winsorized variables.

\begin{tabular}{rrrrrrr}
\hline \hline & & & & & & \\
\cline { 2 - 7 } Log change in exchange rate & $\Delta F X$ & 7.7 & Median & St. Dev. & Min & Max \\
\cline { 2 - 7 } Exchange rate pressure & $\Delta P r e s$ & 7.2 & 2.4 & 23.2 & -33.2 & 482.5 \\
Change in reserves/GDP & $\Delta R$ & 0.4 & 0.2 & 3.7 & -24.4 & 478.5 \\
Net Ex. Assets (inc. Res.)/GDP & $N F A \_w$ & -44.9 & -39.6 & 90.2 & -541 & $1,720.50$ \\
Net Ex. Assets (no Res.)/GDP & $N F A \_w o$ & -60.8 & -50.9 & 56.6 & -287.5 & 141.4 \\
Current Account/GDP & $C A$ & -3.9 & -3.6 & 9.2 & -94.7 & 44.6 \\
Net External Debt Assets/GDP & $D$ & -38.1 & -29.6 & 49.5 & -537.9 & 233.3 \\
Net External PE Assets/GDP & $P E$ & 1.9 & 0 & 59.3 & -64.8 & $1,705.00$ \\
Net External FDI Assets/GDP & $F D I$ & -21.9 & -13.8 & 27.7 & -226.8 & 426.4 \\
Reserves/GDP & $R$ & 13.2 & 10.2 & 12.9 & 0 & 111.9 \\
Gross gov't debt/GDP & $G o v$ & 59.7 & 49.3 & 43.1 & 0.8 & 276.1 \\
GDP growth & $\Delta G D P$ & 4.1 & 4.4 & 5.1 & -54.1 & 49.1 \\
Inflation & $\pi$ & 11.6 & 7.3 & 17.9 & -40.4 & 308.5 \\
\hline \hline
\end{tabular}

Note: the variables are winsorized as follows: dfx and dpres (3 highest and lowest values); ca (3 lowest values); nx_ass_wo (top and bottom 1 percent); ggd_ngdp (top 1 percent); stexd_fx (top 10 percent); dprice (highest value); and $\operatorname{drgdp}$ (3 highest and lowest values).

Table 3: Results from a univariate regression of change in the exchange rate (negative indicates appreciation) on lagged fundamentals.

\begin{tabular}{rrrr}
\hline \hline & Crisis Year & & No-crisis Year \\
\cline { 2 - 2 } Current Account/GDP & -0.083 & & $-0.148^{* * *}$ \\
& $(0.116)$ & & $(0.056)$ \\
Net external assets/GDP & $-0.035^{* *}$ & & $-0.034^{* * *}$ \\
& $(0.017)$ & & $(0.009)$ \\
Reserves/GDP & $-0.217^{* *}$ & & $-0.096^{* *}$ \\
& $(0.088)$ & & $(0.040)$ \\
Gross Gov't Debt/GDP & $0.064^{* * *}$ & $0.034^{* * *}$ \\
& $(0.023)$ & $(0.010)$ \\
\hline \hline notes: Standard errors are in parenthesis. ${ }^{* * * / * * / *}$ denote significance at the 1/5/10\% levels.
\end{tabular}


Table 4: Results from a panel data regression of change in the exchange rate (negative indicates appreciation) on lagged fundamentals.

\begin{tabular}{|c|c|c|c|c|c|c|c|}
\hline \multirow[b]{2}{*}{$C A_{i, t-1}$} & \multicolumn{7}{|c|}{ Dependent variable: $\Delta F X_{i, t}$} \\
\hline & $\begin{array}{c}-0.128^{* * *} \\
(0.048)\end{array}$ & $\begin{array}{c}-0.111^{* *} \\
(0.048)\end{array}$ & $\begin{array}{l}-0.089^{*} \\
(0.052)\end{array}$ & $\begin{array}{l}-0.037 \\
(0.051)\end{array}$ & $\begin{array}{c}-0.015 \\
(0.055)\end{array}$ & $\begin{array}{l}-0.039 \\
(0.052)\end{array}$ & $\begin{array}{l}-0.022 \\
(0.056)\end{array}$ \\
\hline$N F A \_w_{i, t-1}$ & & $\begin{array}{c}-0.013^{* *} \\
(0.005)\end{array}$ & $\begin{array}{l}-0.010^{*} \\
(0.005)\end{array}$ & & & & \\
\hline$N F A_{-} w o_{i, t-1}$ & & & & $\begin{array}{c}-0.037^{* * *} \\
(0.011)\end{array}$ & $\begin{array}{c}-0.032^{* * *} \\
(0.011)\end{array}$ & & \\
\hline$D_{i, t-1}$ & & & & & & $\begin{array}{c}-0.054^{* * *} \\
(0.012)\end{array}$ & $\begin{array}{c}-0.038^{* * *} \\
(0.013)\end{array}$ \\
\hline$P E_{i, t-1}$ & & & & & & $\begin{array}{c}0.004 \\
(0.007)\end{array}$ & $\begin{array}{c}0.003 \\
(0.007)\end{array}$ \\
\hline$F D I_{i, t-1}$ & & & & & & $\begin{array}{l}-0.019 \\
(0.020)\end{array}$ & $\begin{array}{l}-0.027 \\
(0.021)\end{array}$ \\
\hline$R_{i, t-1}$ & & & & $\begin{array}{c}-0.193^{* * *} \\
(0.049)\end{array}$ & $\begin{array}{c}-0.158^{* * *} \\
(0.050)\end{array}$ & $\begin{array}{c}-0.185 * * * \\
(0.049)\end{array}$ & $\begin{array}{c}-0.160^{* * *} \\
(0.050)\end{array}$ \\
\hline$\pi_{i, t-1}$ & $\begin{array}{c}0.387^{* * *} \\
(0.017)\end{array}$ & $\begin{array}{c}0.386^{* * *} \\
(0.017)\end{array}$ & $\begin{array}{c}0.385^{* * *} \\
(0.017)\end{array}$ & $\begin{array}{c}0.381^{* * *} \\
(0.017)\end{array}$ & $\begin{array}{c}0.382^{* * * *} \\
(0.017)\end{array}$ & $\begin{array}{c}0.378^{* * *} \\
(0.017)\end{array}$ & $\begin{array}{c}0.379^{* * *} \\
(0.017)\end{array}$ \\
\hline$\Delta G D P_{i, t-1}$ & $\begin{array}{c}-0.267^{* * *} \\
(0.075)\end{array}$ & $\begin{array}{c}-0.265^{* * *} \\
(0.075)\end{array}$ & $\begin{array}{c}-0.254^{* * *} \\
(0.074)\end{array}$ & $\begin{array}{c}-0.252^{* * *} \\
(0.074)\end{array}$ & $\begin{array}{c}-0.248^{* * *} \\
(0.074)\end{array}$ & $\begin{array}{c}-0.239^{* * *} \\
(0.075)\end{array}$ & $\begin{array}{c}-0.236^{* * *} \\
(0.074)\end{array}$ \\
\hline$X_{t} * C A_{i, t-1}$ & & & $\begin{array}{l}-0.031 \\
(0.109)\end{array}$ & & $\begin{array}{l}-0.118 \\
(0.109)\end{array}$ & & $\begin{array}{l}-0.074 \\
(0.112)\end{array}$ \\
\hline$X_{t} * N F A_{-} w_{i, t-1}$ & & & $\begin{array}{c}-0.074^{* * *} \\
(0.015)\end{array}$ & & & & \\
\hline$X_{t} * N F A_{-} w o_{i, t-1}$ & & & & & $\begin{array}{c}-0.030^{*} \\
(0.017)\end{array}$ & & \\
\hline$X_{t} * D_{i, t-1}$ & & & & & & & $\begin{array}{c}-0.061^{* * *} \\
(0.018)\end{array}$ \\
\hline$X_{t} * P E_{i, t-1}$ & & & & & & & $\begin{array}{c}-0.013 \\
(0.247)\end{array}$ \\
\hline$X_{t} * F D I_{i, t-1}$ & & & & & & & $\begin{array}{c}0 \\
(0.045)\end{array}$ \\
\hline$X_{t} * R_{i, t-1}$ & & & & & $\begin{array}{c}-0.234^{* * *} \\
(0.074)\end{array}$ & & $\begin{array}{c}-0.211^{* * *} \\
(0.075)\end{array}$ \\
\hline Adj R2 & 3,050 & 3,050 & 3,050 & 3,050 & 3,050 & 3,050 & 3,050 \\
\hline Obs & 0.25 & 0.251 & 0.259 & 0.256 & 0.26 & 0.258 & 0.264 \\
\hline Countries & 119 & 119 & 119 & 119 & 119 & 119 & 119 \\
\hline
\end{tabular}


Table 5: Results from a panel data regression of change in the exchange rate pressure index (negative indicates appreciation) on lagged fundamentals.

\begin{tabular}{|c|c|c|c|c|c|c|c|}
\hline \multirow[b]{2}{*}{$C A_{i, t-1}$} & \multicolumn{7}{|c|}{ Dependent variable: $\Delta \operatorname{Pres}_{i, t}$} \\
\hline & $\begin{array}{c}-0.148^{* * *} \\
(0.048)\end{array}$ & $\begin{array}{c}-0.132^{\text {*** }}(0.048)\end{array}$ & $\begin{array}{c}-0.113^{* *} \\
(0.052)\end{array}$ & $\begin{array}{l}-0.083 \\
(0.051)\end{array}$ & $\begin{array}{c}-0.063 \\
(0.055)\end{array}$ & $\begin{array}{l}-0.087^{*} \\
(0.052)\end{array}$ & $\begin{array}{l}-0.074 \\
(0.056)\end{array}$ \\
\hline$N F A \_w_{i, t-1}$ & & $\begin{array}{c}-0.011^{* *} \\
(0.005)\end{array}$ & $\begin{array}{l}-0.008 \\
(0.005)\end{array}$ & & & & \\
\hline$N F A_{-} w o_{i, t-1}$ & & & & $\begin{array}{c}-0.035^{* * *} \\
(0.011)\end{array}$ & $\begin{array}{c}-0.030^{* * *} \\
(0.011)\end{array}$ & & \\
\hline$D_{i, t-1}$ & & & & & & $\begin{array}{c}-0.055^{* * *} \\
(0.012)\end{array}$ & $\begin{array}{c}-0.039^{* * *} \\
(0.013)\end{array}$ \\
\hline$P E_{i, t-1}$ & & & & & & $\begin{array}{c}0.005 \\
(0.007)\end{array}$ & $\begin{array}{c}0.003 \\
(0.007)\end{array}$ \\
\hline$F D I_{i, t-1}$ & & & & & & $\begin{array}{l}-0.013 \\
(0.020)\end{array}$ & $\begin{array}{c}-0.02 \\
(0.021)\end{array}$ \\
\hline$R_{i, t-1}$ & & & & $\begin{array}{l}-0.083^{*} \\
(0.048)\end{array}$ & $\begin{array}{l}-0.041 \\
(0.049)\end{array}$ & $\begin{array}{l}-0.073 \\
(0.049)\end{array}$ & $\begin{array}{l}-0.041 \\
(0.050)\end{array}$ \\
\hline$\pi_{i, t-1}$ & $\begin{array}{c}0.388^{* * *} \\
(0.017)\end{array}$ & $\begin{array}{c}0.387^{* * *} \\
(0.017)\end{array}$ & $\begin{array}{c}0.386^{* * *} \\
(0.017)\end{array}$ & $\begin{array}{c}0.383^{* * *} \\
(0.017)\end{array}$ & $\begin{array}{c}0.384^{* * * *} \\
(0.017)\end{array}$ & $\begin{array}{c}0.380^{* * *} \\
(0.017)\end{array}$ & $\begin{array}{c}0.381^{* * *} \\
(0.017)\end{array}$ \\
\hline$\Delta G D P_{i, t-1}$ & $\begin{array}{c}-0.254^{* * *} \\
(0.074)\end{array}$ & $\begin{array}{c}-0.252^{* * *} \\
(0.074)\end{array}$ & $\begin{array}{c}-0.241^{* * *} \\
(0.074)\end{array}$ & $\begin{array}{c}-0.242^{* * *} \\
(0.074)\end{array}$ & $\begin{array}{c}-0.238^{* * *} \\
(0.074)\end{array}$ & $\begin{array}{c}-0.226^{* * *} \\
(0.074)\end{array}$ & $\begin{array}{c}-0.224^{* * * *} \\
(0.074)\end{array}$ \\
\hline$X_{t} * C A_{i, t-1}$ & & & $\begin{array}{l}-0.022 \\
(0.108)\end{array}$ & & $\begin{array}{l}-0.103 \\
(0.109)\end{array}$ & & $\begin{array}{c}-0.06 \\
(0.112)\end{array}$ \\
\hline$X_{t} * N F A_{-} w_{i, t-1}$ & & & $\begin{array}{c}-0.075^{* * *} \\
(0.015)\end{array}$ & & & & \\
\hline$X_{t} * N F A_{-} w o_{i, t-1}$ & & & & & $\begin{array}{c}-0.029^{*} \\
(0.016)\end{array}$ & & \\
\hline$X_{t} * D_{i, t-1}$ & & & & & & & $\begin{array}{c}-0.060^{* * *} \\
(0.018)\end{array}$ \\
\hline$X_{t} * P E_{i, t-1}$ & & & & & & & $\begin{array}{c}0.021 \\
(0.246)\end{array}$ \\
\hline$X_{t} * F D I_{i, t-1}$ & & & & & & & $\begin{array}{c}0.002 \\
(0.045)\end{array}$ \\
\hline$X_{t} * R_{i, t-1}$ & & & & & $\begin{array}{c}-0.281^{* * *} \\
(0.074)\end{array}$ & & $\begin{array}{c}-0.257^{* * * *} \\
(0.075)\end{array}$ \\
\hline Adj R2 & 3,050 & 3,050 & 3,050 & 3,050 & 3,050 & 3,050 & 3,050 \\
\hline Obs & 0.248 & 0.249 & 0.256 & 0.251 & 0.256 & 0.253 & 0.26 \\
\hline Countries & 119 & 119 & 119 & 119 & 119 & 119 & 119 \\
\hline
\end{tabular}


Table 6: Results from a panel data regression of change in the exchange rate (negative indicates appreciation) or exchange rate pressure on lagged fundamentals.

\begin{tabular}{|c|c|c|c|c|}
\hline \multirow{3}{*}{$C A_{i, t-1}$} & \multicolumn{2}{|c|}{ Dependent variable: $\Delta F X_{i, t}$} & \multicolumn{2}{|c|}{ Dependent variable: $\Delta$ Pres $_{i, t}$} \\
\hline & -0.017 & -0.013 & -0.064 & -0.063 \\
\hline & $(0.050)$ & $(0.054)$ & $(0.050)$ & $(0.054)$ \\
\hline \multirow{2}{*}{$N F A_{-} w o_{i, t-1}$} & 0.006 & 0.003 & 0.008 & 0.004 \\
\hline & $(0.014)$ & $(0.014)$ & $(0.014)$ & $(0.014)$ \\
\hline \multirow[t]{2}{*}{$R_{i, t-1}$} & $-0.152^{* * *}$ & $-0.122^{* *}$ & -0.041 & -0.004 \\
\hline & $(0.048)$ & $(0.049)$ & $(0.048)$ & $(0.049)$ \\
\hline \multirow[t]{2}{*}{$\operatorname{Gov}_{i, t-1}$} & $0.062^{* * *}$ & $0.055^{* * *}$ & $0.063^{* * *}$ & $0.055^{* * *}$ \\
\hline & $(0.016)$ & $(0.018)$ & $(0.016)$ & $(0.017)$ \\
\hline \multirow{2}{*}{$\pi_{i, t-1}$} & $0.385^{* * *}$ & $0.385^{* * *}$ & $0.388^{* * *}$ & $0.388^{* * *}$ \\
\hline & $(0.017)$ & $(0.017)$ & $(0.017)$ & $(0.017)$ \\
\hline \multirow[t]{2}{*}{$\Delta G D P_{i, t-1}$} & $-0.294^{* * *}$ & $-0.294^{* * *}$ & $-0.291^{* * *}$ & $-0.291^{* * *}$ \\
\hline & $(0.073)$ & $(0.073)$ & $(0.073)$ & $(0.073)$ \\
\hline \multirow{2}{*}{$X_{t} * C A_{i, t-1}$} & & -0.013 & & 0.004 \\
\hline & & $(0.108)$ & & $(0.108)$ \\
\hline \multirow[t]{2}{*}{$X_{t} * N F A_{-} w o_{i, t-1}$} & & 0.014 & & 0.015 \\
\hline & & $(0.020)$ & & $(0.020)$ \\
\hline \multirow{2}{*}{$X_{t} * R_{i, t-1}$} & & $-0.227^{* * *}$ & & $-0.276^{* * *}$ \\
\hline & & $(0.072)$ & & $(0.071)$ \\
\hline \multirow{2}{*}{$X_{t} * \operatorname{Gov}_{i, t-1}$} & & 0.025 & & 0.029 \\
\hline & & $(0.023)$ & & $(0.023)$ \\
\hline Adj R2 & 2,981 & 2,981 & 2,981 & 2,981 \\
\hline Obs & 0.279 & 0.281 & 0.273 & 0.277 \\
\hline Countries & 119 & 119 & 119 & 119 \\
\hline
\end{tabular}

